\title{
Follistatin concentrations in maternal and fetal fluids during the oestrous cycle, gestation and parturition in Merino sheep
}

\author{
J. R. McFarlane ${ }^{1}$, Y. Xia ${ }^{1}$, T. O'Shea ${ }^{1}$, S. Hayward ${ }^{2}$, \\ A. E. O'Connor ${ }^{2}$ and D. M. de Kretser ${ }^{2}$ \\ ${ }^{1}$ Discipline of Physiology, University of New England, Armidale NSW 2351, Australia; and \\ ${ }^{2}$ Monash Institute of Reproduction and Development, Monash University, Melbourne, \\ Victoria 3168, Australia
}

The aim of this study was to investigate the changes in follistatin, an activin binding protein, during the oestrous cycle, gestation and parturition in ewes using a radioimmunoassay for total follistatin, which uses dissociating reagents to remove the interference of activin. Follistatin concentrations remained unchanged $\left(2.7 \pm 0.2 \mathrm{ng} \mathrm{ml}^{-1}\right)$ during the oestrous cycle and decreased as pregnancy progressed. Follistatin concentrations in allantoic fluid also decreased during gestation, whereas in amniotic fluid follistatin concentrations reached a peak at day 75 of gestation (9.8 $\mathrm{ng} \mathrm{ml}^{-1}$ ) and had decreased to $4.4 \mathrm{ng} \mathrm{ml}^{-1}$ at day 140. Follistatin concentrations in fetal blood $\left(7.0 \pm 0.5 \mathrm{ng} \mathrm{ml}^{-1}\right)$ did not change from day 50 to day 140 of gestation but were significantly higher than in matched maternal samples $\left(3.1 \pm 0.3 \mathrm{ng} \mathrm{ml}^{-1}\right)$. Circulating follistatin in ewes was significantly increased on the day of parturition $\left(5.6 \pm 0.6 \mathrm{ng} \mathrm{ml}^{-1}\right)$ compared with the days before parturition $\left(2.7 \pm 0.4 \mathrm{ng} \mathrm{ml}^{-1}\right)$, but had decreased by day 2 after birth. Blood samples from newborn lambs showed that plasma follistatin concentration $\left(13.4 \pm 2.3 \mathrm{ng} \mathrm{ml}^{-1}\right)$ was significantly higher than that of the mothers and remained high for at least 7 days after birth. These data support previous studies of the human menstrual cycle indicating that follistatin is not an endocrine signal from the ovary; however, in contrast to human pregnancies, follistatin concentrations in sheep decreased and become high only after or during parturition. This difference observed between species may reflect different physiological effects of follistatin or may be the result of measurement of different isoforms.

\section{Introduction}

Activins are homo- and heterodimers of the inhibin $\beta_{A}$ and $\beta_{B}$ subunits, which form activin $A$, activin $B$ and activin $A B$. The activins were initially identified by their capacity to stimulate the secretion of FSH by pituitary cells in culture (Ling et al., 1986; Vale et al., 1986). More recent studies have shown that activins have a wide range of actions in a variety of other tissues (Mather et al., 1997). Activins were first implicated in pregnancy when the mRNAs for the $\beta_{A}$ and $\beta_{B}$ subunits were identified in the placenta (Meunier et al., 1988) and fetal membranes (Petraglia et al., 1993). The dimeric proteins were subsequently identified in the placenta (de Kretser et al., 1994a; Yokoyama et al., 1995). High concentrations of activin A have been recorded in ovine amniotic fluid (Wongprasartsuk et al., 1994; de Kretser et al., 1994b) and allantoic fluid (Foulds et al., 1998). A number of studies have shown that activin A concentrations are high in the plasma of pregnant women (Muttukrishna et al., 1996; Woodruff et al., 1997; Fowler et al., 1998) and, more recently, O'Connor et al. (1999) showed that activin A concentration increases throughout human pregnancy, particularly in the third trimester. The

Email:jmcfarla@metz.une.edu.au inhibin/activin subunits are expressed by granulosa cells in developing antral follicles and are probably important in regulating proliferation and function of granulosa cells (Findlay, 1993), and, hence, follicular development (Schneyer et al., 2000). Activin A has also been shown to vary biphasically during the menstrual cycle in women, with peaks occurring mid-cycle and during the late luteal early follicular phase (Muttukrishna et al., 1996).

The role of activin in many biological systems is thought to be modulated by follistatin, a high affinity activin binding protein, which can neutralize most of the biological actions of activin (Nakamura et al., 1990; Kogawa et al., 1991; Mather et al., 1993). Follistatin was first identified in follicular fluid as an inhibitor of FSH secretion by the pituitary, although its potency was only $10-30 \%$ of that of inhibin (Robertson et al., 1987; Ueno et al., 1987). Subsequently, follistatin was shown to be a binding protein of both activin and inhibin, and, more recently, several bone morphogenic proteins (BMPs) (lemura et al., 1998). Follistatin exists as a variety of isoforms, which are the product of at least two alternatively spliced forms; there are at least six forms of this protein with molecular masses ranging from $31 \mathrm{kDa}$ to $45 \mathrm{kDa}$ after proteolytic cleavage and variable glycosylation (Robertson et al., 1987; Ueno et al., 1987; Sugino et al., 1993). Recent data using surface 
plasmon resonance technology demonstrate that some isoforms have a higher affinity for activin than do others (Hashimoto et al., 2000); hence, these isoforms may have different physiological functions.

Follistatin has been isolated from human placenta and has been identified in human and ovine fetal membranes and fluids (de Kretser et al., 1994a,b; Petraglia et al., 1994a,b). Serum follistatin concentrations increase during pregnancy in women, particularly near term (Woodruff et al., 1997; O'Connor et al., 1999). Follistatin mRNA and protein have been localized to the granulosa cells in the ovary (Nakamura et al., 1991). Although expression of follistatin mRNA is at a maximum in the rat ovary at oestrus, corresponding protein concentrations in the ovary and serum do not change significantly (Mercado et al., 1993). These data are supported by studies of women showing little change in follistatin concentrations during the menstrual cycle (Khoury et al., 1995).

The aim of the present study was to study comprehensively the concentrations of follistatin in maternal plasma during the ovine oestrous cycle and pregnancy, and to measure follistatin concentrations in fetal plasma and fluids. The secondary aim was to assess the usefulness of sheep as a model for these kinds of studies, thus allowing more intensive investigation than is possible with human subjects.

\section{Materials and Methods}

\section{Ethical approval of animal experiments}

These experiments were approved by the University of New England Animal Ethics Committee and conform to the NHMRC/CSIRO/AAC Code of Practice for the Care and Use of Animals for Experimental Purposes.

\section{Animal treatments}

A group of five Merino ewes was kept with two castrated male Merino sheep (wethers) that had received injections of $50 \mathrm{mg}$ mixed testosterone esters (Durateston; Intervet, Castle Hill) over the previous 2 months. The wethers were harnessed with marking crayons so that the day of oestrus could be determined. Blood samples were taken once a day until the ewes were marked again, indicating the next oestrus. A flock of 50 ewes was kept with intact rams harnessed with marking crayons to determine the conception date. Blood samples were taken once a week and groups of five ewes were killed at days 50, 75, 100, 125 and 140 of gestation. Cord blood, amniotic and allantoic fluid samples were also collected. A further group of five ewes was allowed to give birth and blood samples were collected once a day for the last 10 days before parturition and on days 1,2 and 7 after parturition. Blood samples were collected from the lambs of these ewes, together with a further group of seven lambs and ewes, on days 1, 2 and 7 after parturition.

Blood samples were collected by venepuncture from the jugular vein and added to heparin-coated tubes. The use of heparin as an anticoagulant does not interfere with the assay. The blood was centrifuged at approximately $1400 \mathrm{~g}$ for $30 \mathrm{~min}$ and the plasma was removed and stored at $-20^{\circ} \mathrm{C}$ until assayed.

\section{Hormone assays}

Follistatin was measured using a radioimmunoassay as described by Phillips et al. (1996). In brief, this assay uses a rabbit antiserum (No. 202) raised against bovine $39 \mathrm{kDa}$ follistatin purified from follicular fluid. A heterologous bovine follistatin pool (35, 39 and $45 \mathrm{kDa})$, which was isolated from bovine follicular fluid as described by Klein et al. (1991), was used as standard and tracer. The follistatin pool $(2.5 \mu \mathrm{g})$ was iodinated $(0.5 \mathrm{mCi})$ using lodogen (500 ng; Pierce, Rockford, IL). Separation of bound from free follistatin was achieved by goat anti-rabbit second antibody precipitation in the presence of $0.9 \%(\mathrm{w} / \mathrm{v})$ saline. Bovine inhibin, human recombinant inhibin and human recombinant activin show $<0.5 \%$ crossreactivity in the assay. Dissociating reagents were used to eliminate the interference of activin, as described by McFarlane et al. (1996). The sensitivity of the assay was $1.0 \mathrm{ng} \mathrm{ml}^{-1}$ and the inter- and intra-assay coefficients of variation were 13.0 and $8.0 \%$, respectively.

Samples were assayed for progesterone using a similar procedure to that described by McFarlane et al. (1990). The antiserum was prepared using progesterone-11 $\alpha$-HS-BSA (No. 230; Bioquest Limited, North Ryde). Each sample was extracted in duplicate with a ten times volume of diethyl ether. The sensitivity of the assay was $25 \mathrm{pg} \mathrm{ml}^{-1}$. The interassay coefficient of variation was $11 \%$ and the intra-assay coefficient of variation was $4 \%$.

\section{Data analysis}

Parallel-line statistics (Finney, 1978), regression analysis and one-way ANOVA followed by a Student-NewmanKeuls multiple range test were performed using the SAS computer software package (SAS Institute Inc., Cary, NC). The data were log-transformed before analysis to normalize the data and to equalize the variance.

\section{Results}

Blood samples were collected once a day from a group of five ewes from the day they showed oestrus until they were marked again, indicating the start of the next ovarian cycle. The concentrations of follistatin measured in these daily samples are shown (Fig. 1). Follistatin concentrations did not change significantly during the oestrous cycle (Fig. 1), with an overall mean concentration of $2.7 \pm 0.2 \mathrm{ng} \mathrm{ml}^{-1}$.

Follistatin concentrations in plasma samples taken at weekly intervals from pregnant and non-pregnant ewes from the day of oestrus until day 140 of gestation are shown (Fig. 2). In the non-pregnant ewes, follistatin concentrations did not change significantly and although the concentrations appeared to increase in the last half of gestation this increase was not significant. In the pregnant ewes, follistatin 


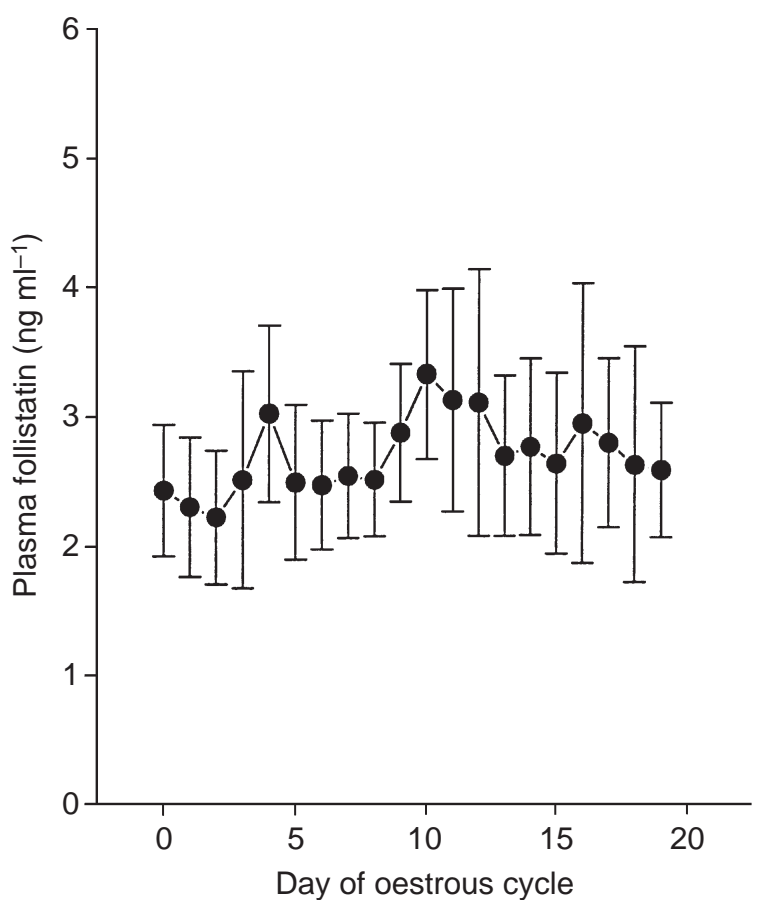

Fig. 1. Concentration of follistatin in plasma samples from cyclic ewes, with day 0 as the day of oestrus. Data are mean \pm SE $(n=5)$.

concentrations decreased significantly overall $(P<0.02)$ from $4.2 \pm 0.1 \mathrm{ng} \mathrm{ml}^{-1}$ to $2.8 \pm 0.1 \mathrm{ng} \mathrm{ml}^{-1}$ at day 140 of gestation. Plasma follistatin concentrations were significantly lower in pregnant ewes than in non-pregnant ewes from day 100 to day 140 of gestation. This period coincided with the increase in plasma progesterone concentration, which occurred at approximately day 90 of gestation (Fig. 2).

Allantoic fluid was collected from groups of ewes killed at approximately days 50, 75, 100, 125 and 140 of gestation. Regression analysis demonstrated that follistatin concentrations, although variable, decreased significantly $(P<0.001)$ from day 50 to day 140 of gestation (Fig. 3$)$. The follistatin profile in amniotic fluid was different from that observed in allantoic fluid, and the concentrations of follistatin in amniotic fluid were significantly $(P<0.05)$ lower than those recorded in allantoic fluid. The peak concentrations were on days 75 and 100, which were significantly $(P<0.01)$ higher than on days 50,125 and 140 (Fig. 4).

Follistatin concentrations in fetal plasma were significantly higher $(P<0.01)$ than in maternal plasma from day 75 to day 140 of gestation. Although the fetal plasma concentrations of follistatin showed a decrease with gestational age, this was not significant. Matched maternal samples taken just before the ewes were killed did not change significantly from day 75 to day 140 of gestation (Fig. 5).

Blood samples were collected once a day from day 10 before the expected day of parturition, on the day of birth and on days 1,2 and 7 after birth to monitor the changes in follistatin concentration at about the time of parturition more closely. A significant $(P<0.05)$ increase in follistatin
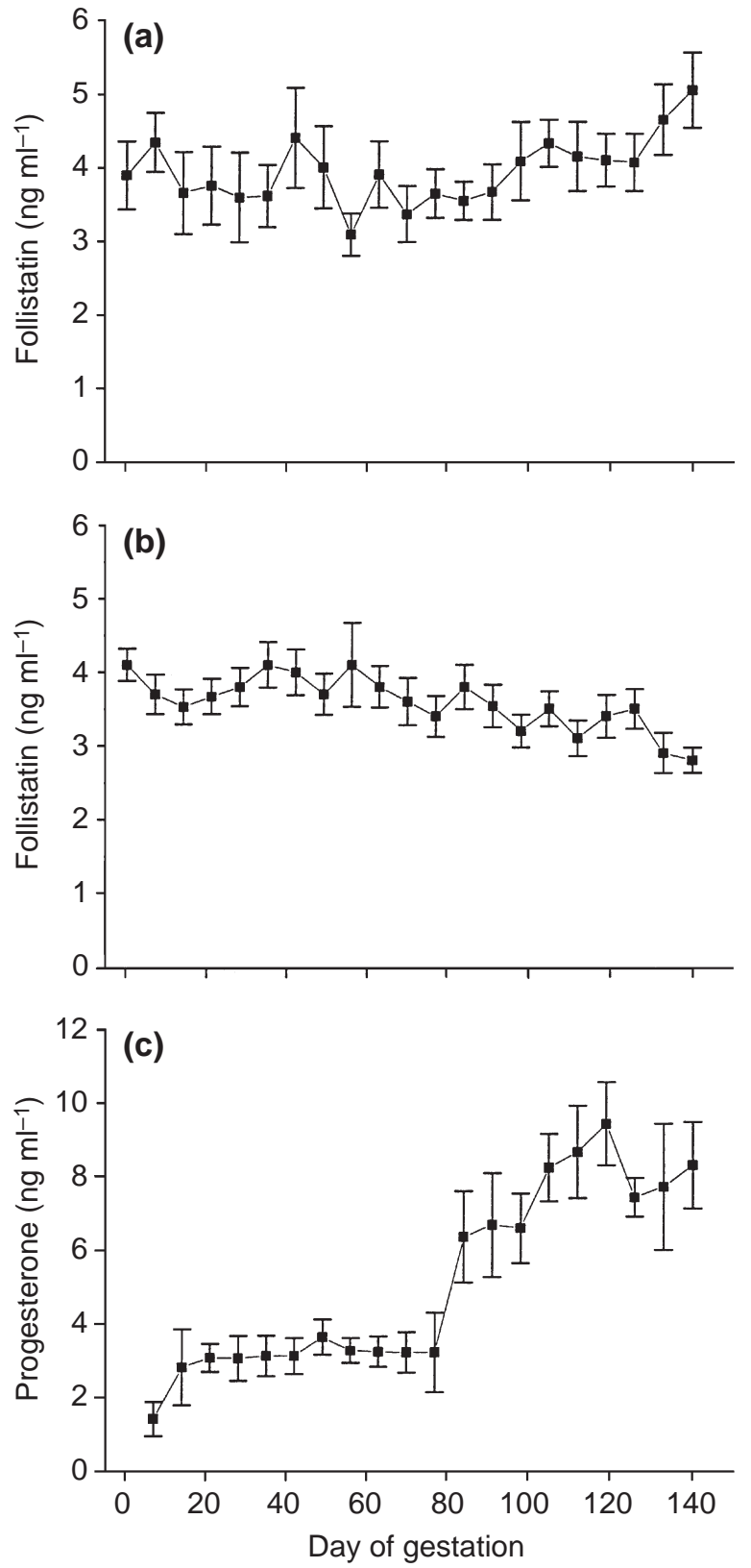

Fig. 2. Weekly plasma concentrations of follistatin in (a) nonpregnant control ewes $(n=5)$ and concentrations of (b) follistatin and (c) progesterone in pregnant ewes $(n=10-35)$ from the day of oestrus (day 0 ) until day 140 of gestation. Data are mean \pm SE.

concentration in ewes was observed on the day of parturition and on day 1 after parturition (Fig. 6). These concentrations decreased on day 2 and by day 7 after parturition concentrations were not significantly different from those before parturition.

Follistatin was measured in blood samples taken from lambs and their mothers on the day of parturition and on days 1,2 and 7 after parturition (Fig. 7). Follistatin concentrations in the plasma of the lambs were significantly higher $(P<0.001)$ than plasma concentrations in the 


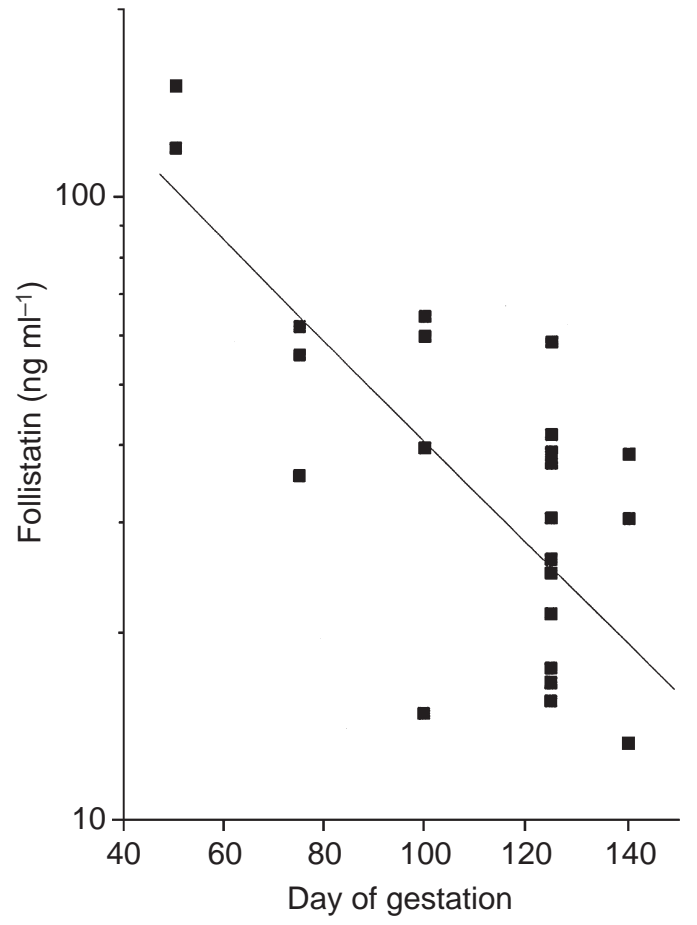

Fig. 3. Follistatin concentrations in sheep allantoic fluid collected at days 50, 75, 100, 125 and 140 of gestation. A linear regression line $(R=-0.7208)$ described by the equation $y=-0.0081 x+$ 2.4141 is shown fitted to the data. Note the logarithmic scale.

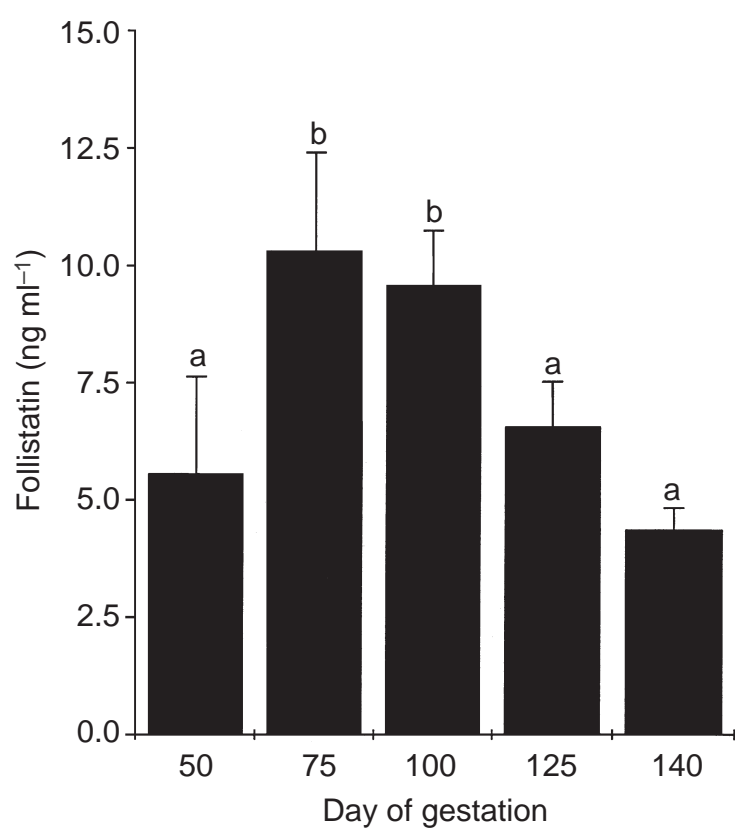

Fig. 4. Follistatin concentrations in sheep amniotic fluid $(n=3-13)$ collected at days 50, 75, 100, 125 and 140 of gestation. Data are mean $\pm \mathrm{SE}$. ${ }^{\mathrm{ab}}$ Concentrations with different letters are significantly different $(P<0.05)$.

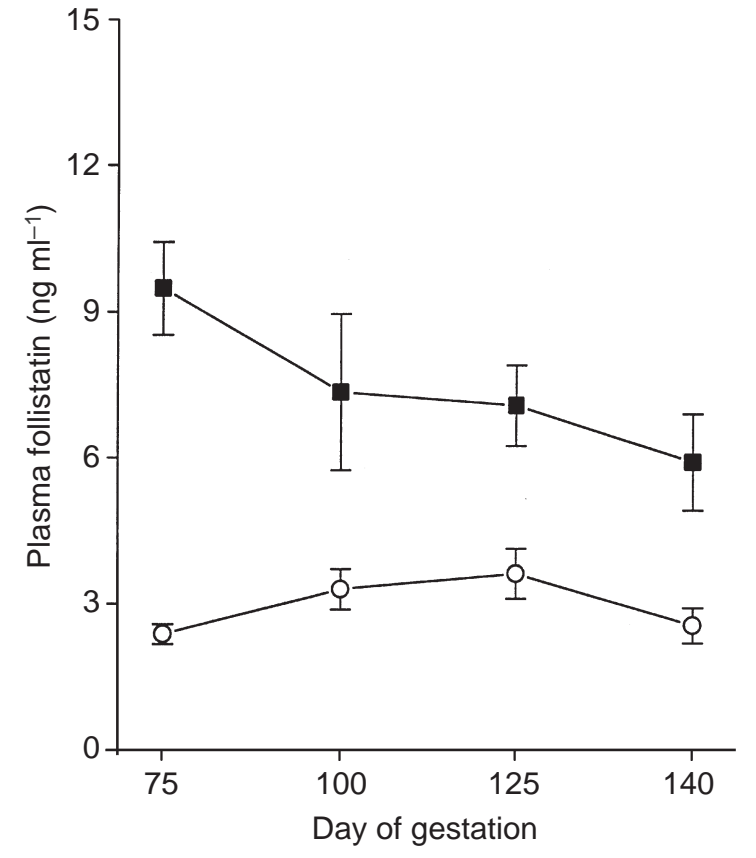

Fig. 5. Follistatin concentrations in plasma taken from sheep fetuses $(\square ; n=4-10)$ at days $75,100,125$ and 140 of gestation compared with follistatin concentrations in matched maternal plasma $(\bigcirc)$ at the same times. Data are mean $\pm \mathrm{SE}$.

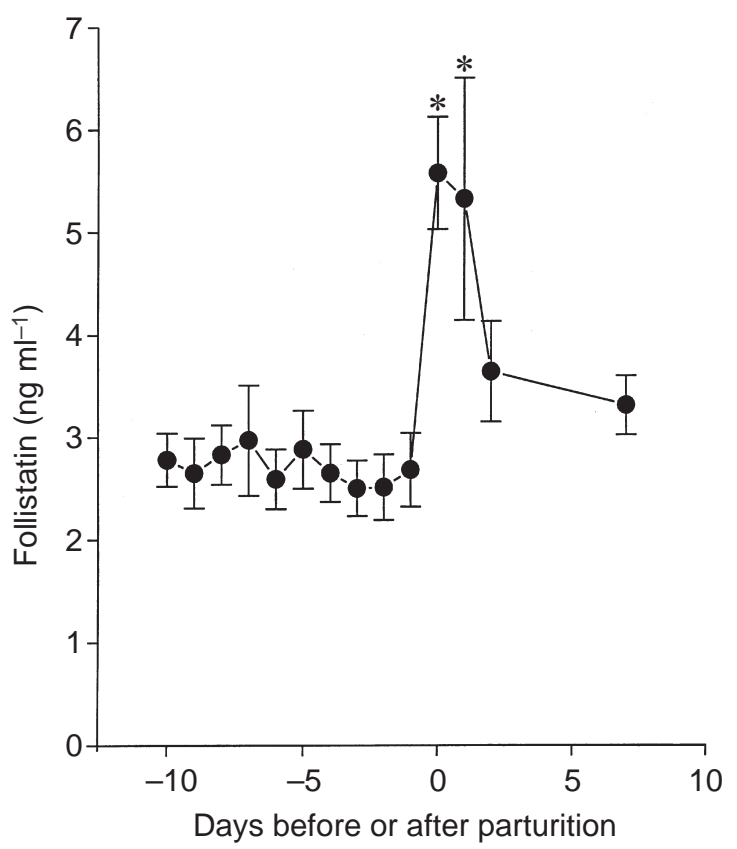

Fig. 6. Daily follistatin concentrations in ewes $(n=10)$ from day 10 before parturition to day 7 after lambing. Day 0 is the day of parturition. Data are mean $\pm \mathrm{SE} .{ }^{*}$ Concentrations with asterisks are significantly different from other values $(P<0.05)$. 


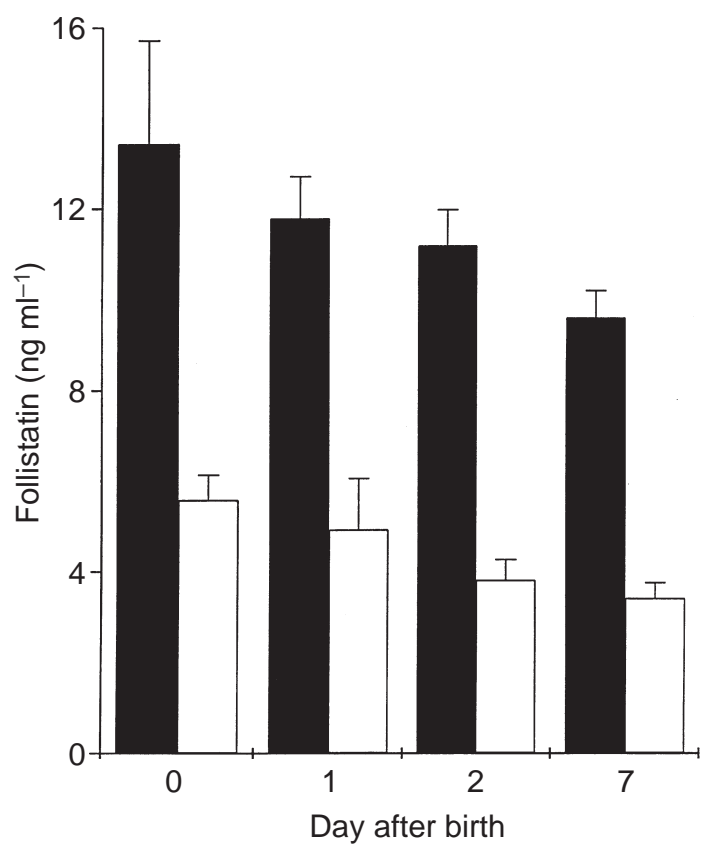

Fig. 7. Follistatin concentrations in the plasma of lambs $(\mathbf{\square}, n=10)$ and ewes $(\square, n=10)$ on the day of birth and on days 1,2 and 7 after birth.

mothers. Although the concentrations appeared to decrease over the week, this decrease was not significant. The follistatin concentrations observed in the lambs were also significantly higher $(P<0.01)$ than those measured in fetuses during late gestation.

\section{Discussion}

In the present study we have described the profiles of circulating follistatin in ewes during the oestrous cycle and during pregnancy using an assay that is not interfered with by activin. There were no significant differences in plasma follistatin concentrations in ewes during the oestrous cycle. Although follistatin mRNA in rats (Nakatani et al., 1991) and sheep (Tisdall et al., 1994), and follistatin protein as determined by immunocytochemistry in cattle (Singh and Adams 1998), increase with follicular development this is not reflected in plasma follistatin concentrations. This finding is in contrast to that reported previously by Klein et al. (1993), but is similar to that reported in humans (Khoury et al., 1995). The previous study by Klein et al. (1993) used a radioimmunoassay for follistatin that was subsequently found to be interfered with by activin (de Kretser et al., 1994a). It is likely that the increased follistatin concentration reported by Klein et al. (1993) in the luteal phase of the oestrous cycle may be a result of interference with activin or other growth factors, which bind to follistatin. The data from this study and previous studies using a variety of assays for follistatin (Kettel et al., 1996; Evans et al., 1998; McConnell et al., 1998) support the concept proposed by Khoury et al. (1995) that follistatin, or at least the isoforms detected in the assays, does not have an endocrine role during the oestrous or menstrual cycle.
Follistatin concentrations measured in human maternal plasma using a variety of assays increase as pregnancy progresses, particularly in the last trimester (Wakatsuki et al., 1996; Woodruff et al., 1997; Fowler et al., 1998; O'Connor et al., 1999; Schneider-Kolsky et al., 2000). In contrast, the plasma concentrations of follistatin in sheep did not increase during pregnancy but instead decreased slightly. The decrease in follistatin concentrations during gestation in sheep was unexpected but may indicate that there are species differences in the physiology of follistatin during pregnancy. The secretion of inhibin A does not increase during the follicular phase of the oestrous cycle in ewes (Knight et al., 1998), in contrast to the increase observed during the human menstrual cycle (Groome et al., 1994) and the rat oestrous cycle (Fahy et al., 1996). During pregnancy in ewes, plasma inhibin A concentrations decreased at day 60 and remained low until late in gestation (Findlay et al., 1991; Knight et al., 1998), whereas in humans circulating inhibin A concentrations increase, particularly in the third trimester (Muttukrishna et al., 1995).

Follistatin content in the allantoic fluid compartment was highest early in gestation and decreased significantly $(P<0.01)$, as determined by log-linear regression analysis, as pregnancy progressed. In contrast, the concentrations of follistatin in amniotic fluid were highest at mid-gestation and then decreased until term. These findings are similar to data from human pregnancies showing that the concentrations were higher near mid-gestation and significantly lower near term (Evans et al., 1998). The source of follistatin in these fluids is likely to be the fetal membranes (Keelan et al., 1999) or the placenta (de Kretser et al., 1994a; Petraglia et al., 1994b; Yokoyama et al., 1995) or both, which have been shown to produce follistatin. The difference in patterns of concentrations between the allantoic and the amniotic fluids implies that the source of the follistatin in the compartments is not the same and is differentially regulated.

Follistatin concentrations in plasma from sheep fetuses were up to three times higher than matched samples of maternal plasma. Follistatin is expressed by a number of tissues in the fetus (Roberts and Barth, 1994) and expression may be increased in these tissues to modulate the effects of activins and other transforming growth factor $\beta$ (TGF- $\beta$ ) family members during development. Evidence from studies of liver after partial hepatectomy show that follistatin mRNA is upregulated and that exogenous intravenous follistatin promotes more rapid regrowth of the liver than in untreated animals (Kogure et al., 1995, 1996).

Follistatin concentrations increased significantly on the day of parturition and remained high for at least $24 \mathrm{~h}$ before decreasing on day 3 after parturition. This profile is very similar to that observed after surgery (Klein et al., 1993) or after injection of interleukin $1 \beta$ (Phillips et al., 1996). Inflammatory cytokine concentrations increase during labour in humans (Opsjøn et al., 1993) and stimulate activin A secretion by the placenta (Mohan et al., 2001). However, the observation that follistatin concentration was increased in maternal plasma after the expulsion of the fetal mem- 
branes indicates that the source of follistatin is probably maternal rather than fetal. This increase in follistatin after parturition may be due to the tissue damage and cytokine cascade resulting from the birth and it is possible that follistatin is not directly implicated in parturition.

After birth, plasma concentrations of follistatin in the lambs were increased compared with concentrations a few days before parturition. These high concentrations were significantly greater than those observed in matched maternal plasma and remained high for at least 7 days after birth. Although similar data are not available from other species, a study by Kettel et al. (1996) indicates that follistatin is higher in adults and postmenopausal women than in girls in early adolescence. Although these results are not directly comparable, they do indicate that circulating follistatin may be dynamically regulated during development and that sexual maturation may occur in response to the changing concentrations of activin.

A number of other follistatin-like molecules have been reported (Zwijsen et al., 1994; Hayette et al., 1998; Tsuchida et al., 2000) that may crossreact in the follistatin assays used in the present study. Of these, the follistatin-like protein (FLRG) is most closely related (Hayette et al., 1998); it has two follistatin domains that are able to neutralize the bioactivity of activin (Tsuchida et al., 2000). It is also highly expressed in a range of tissues including the placenta (Tsuchida et al., 2000); thus, if it crossreacts in a follistatin assay it will contribute to the overall concentrations reported. Until these proteins have been tested for crossreactivity in the various assays used to measure follistatin and until our knowledge of their physiology improves some caution must be taken when interpreting the current follistatin assay data.

In conclusion, the results of the present study indicate that follistatin has an important role during development and early neonatal life, and that the follistatin dynamics during pregnancy in sheep are not similar to those in humans. Hence, in this respect, the sheep is perhaps not a good model of human pregnancy. However, undertaking these comparative studies is likely to enhance our understanding of the roles of follistatin and activin during pregnancy and parturition in general.

The authors would like to thank G. Chaffey for technical and animal handling assistance. This work was supported in part by grants from the Kent Hughes Foundation and the National Health and Medical Research Council of Australia.

\section{References}

de Kretser DM, Foulds LM, Hancock M and Robertson DM (1994a) Partial characterization of inhibin, activin, and follistatin in term human placenta Journal of Clinical Endocrinology and Metabolism 79 502-507

de Kretser DM, Foulds LM, Hancock M, McFarlane JR, Goss $\mathbf{N}$ and Jenkin G (1994b) The isolation of activin from ovine amniotic fluid Endocrinology 134 1231-1237

Evans LW, Muttukrishna S and Groome NP (1998) Development, validation and application of an ultra-sensitive two-site enzyme immunoassay for human follistatin Journal of Endocrinology 156 275-282

Fahy PA, Wilson CA, Beard AJ, Groome NP and Knight PG (1995) Changes in inhibin-A (alpha-beta A dimer) and total alpha inhibin in the peripheral circulation and ovaries of rats after gonadotrophin-induced follicular development and during the normal oestrous cycle Journal of Endocrinology 147 271-283

Findlay JK (1993) An update on the roles of inhibin, activin, and follistatin as local regulators of folliculogenesis Biology of Reproduction 48 15-23

Findlay JK, Doughton BW and Russell DL (1991) Peripheral concentrations of immunoreactive inhibin during pregnancy and parturition in the ewe Reproduction, Fertility and Development 3 543-549

Finney DJ (1978) Statistical Methods in Biological Assay Griffin, London

Foulds LM, de Kretser DM, Farnworth P, Buttress D, Jenkin G, Groome NP and McFarlane JR (1998) Ovine allantoic fluid contains high concentrations of activin A: partial dissociation of immunoactivity and bioactivity Biology of Reproduction 59 233-240

Fowler PA, Evans LW, Groome NP, Templeton A and Knight PG (1998) A longitudinal study of maternal serum inhibin- $A$, inhibin-B, activin-A, activin- $A B$, pro-alphaC and follistatin during pregnancy Human Reproduction 13 3530-3536

Groome NP, Illingworth PJ, O'Brien M, Cooke I, Ganesan TS, Baird DT and McNeilly AS (1994) Detection of dimeric inhibin throughout the human menstrual cycle by two-site enzyme immunoassay Clinical Endocrinology $40717-723$

Hashimoto O, Kawasaki N, Tsuchida K, Shimasaki S, Hayakawa T and Sugino H (2000) Difference between follistatin isoforms in the inhibition of activin signalling: activin neutralizing activity of follistatin isoforms is dependent on their affinity for activin Cell Signalling 12 565-571

Hayette S, Gadoux M, Martel S, Bertrand S, Tigaud I, Magaud JP and Rimokh R (1998) FLRG (follistatin-related gene), a new target of chromosomal rearrangement in malignant blood disorders Oncogene 16 2949-2954

Iemura S, Yamamoto TS, Takagi C, Uchiyama H, Natsume T, Shimasaki S, Sugino $\mathbf{H}$ and Ueno $\mathbf{N}$ (1998) Direct binding of follistatin to a complex of bone-morphogenetic protein and its receptor inhibits ventral and epidermal cell fates in early Xenopus embryo Proceedings National Academy of Sciences USA 95 9337-9342

Keelan JA, Marvin KW, Sato TA, McCowan LM, Coleman M, Evans LW, Groome NP and Mitchell MD (1999) Concentrations of activin A, inhibin $A$ and follistatin in human amnion, choriodecidual and placental tissues at term and preterm Journal of Endocrinology 163 99-106

Kettel LM, Depaolo LV, Morales AJ, Apter D, Ling N and Yen SSC (1996) Circulating levels of follistatin from puberty to menopause Fertility and Sterility 65 472-476

Khoury RH, Wang QF, Crowley WF, Jr, Hall JE, Schneyer AL, Toth T, Midgley AR, Jr and Sluss PM (1995) Serum follistatin levels in women: evidence against an endocrine function of ovarian follistatin Journal of Clinical Endocrinology and Metabolism 80 1361-1368

Klein R, Robertson DM, Shukovski L, Findlay JK and de Kretser DM (1991) The radioimmunoassay of follicle-stimulating hormone (FSH)suppressing protein (FSP): stimulation of bovine granulosa cell FSP secretion by FSH Endocrinology 128 1048-1056

Klein R, Findlay JK, Clarke IJ, de Kretser DM and Robertson DM (1993) Radioimmunoassay of FSH-suppressing protein in the ewe: concentrations during the oestrous cycle and following ovariectomy Journal of Endocrinology 137 433-443

Knight PG, Feist SA, Tannetta DS, Bleach EC, Fowler PA, $\mathbf{O}^{\prime}$ Brien M and Groome NP (1998) Measurement of inhibin-A (alpha beta A dimer) during the oestrous cycle, after manipulation of ovarian activity and during pregnancy in ewes Journal of Reproduction and Fertility 113 159-166

Kogawa K, Nakamura T, Sugino K, Takio K, Titani K and Sugino H (1991) Activin-binding protein is present in pituitary Endocrinology $\mathbf{1 2 8}$ 1434-1440

Kogure K, Omata W, Kanzaki M, Zhang YQ, Yasuda H, Mine T and Kojima I (1995) A single intraportal administration of follistatin accelerates liver regeneration in partially hepatectomized rats Gastroenterology $\mathbf{1 0 8}$ 1136-1142

Kogure K, Zhang YQ, Kanzaki M, Omata W, Mine T and Kojima I (1996) Intravenous administration of follistatin - delivery to the liver and effect on liver regeneration after partial hepatectomy Hepatology 24 361-366

Ling N, Ying SY, Ueno N, Shimasaki S, Esch F, Hotta M and Guillemin R 
(1986) A homodimer of the beta-subunits of inhibin A stimulates the secretion of pituitary follicle stimulating hormone Biochemical and Biophysical Research Communications 138 1129-1137

McConnell DS, Wang Q, Sluss PM et al. (1998) A two-site chemiluminescent assay for activin-free follistatin reveals that most follistatin circulating in men and normal cycling women is in an activin-bound state Journal of Clinical Endocrinology and Metabolism 83 851-858

McFarlane JR, Carrick FN, Gemmell RT and MacDonald B (1990) Seasonal effects on androgen secretion in the male Northern Brown Bandicoot, Isoodon macrourus. In Bandicoots and Billbies Eds JH Seebeck et al. pp 251-257. Surrey Beatty and Sons, Sydney

McFarlane JR, Foulds LM, Pisciotta A, Robertson DM and de Kretser DM (1996) Measurement of activin in biological fluids by radioimmunoassay, utilizing dissociating agents to remove the interference of follistatin European Journal of Endocrinology 134 481-489

Mather JP, Roberts PE and Krummen LA (1993) Follistatin modulates activin activity in a cell- and tissue-specific manner Endocrinology 132 $2732-2734$

Mather JP, Moore A and Li RH (1997) Activins, inhibins, and follistatins: further thoughts on a growing family of regulators Proceedings of the Society for Experimental Biology and Medicine 215 209-222

Mercado M, Shimasaki S, Ling N and DePaolo L (1993) Effects of estrous cycle stage and pregnancy on follistatin gene expression and immunoreactivity in rat reproductive tissues: progesterone is implicated in regulating uterine gene expression Endocrinology 132 1774-1781

Meunier H, Rivier C, Evans RM and Vale W (1988) Gonadal and extragonadal expression of inhibin alpha, beta $\mathrm{A}$, and beta $\mathrm{B}$ subunits in various tissues predicts diverse functions Proceedings National Academy of Sciences USA 85 247-251

Mohan A, Asselin J, Sargent IL, Groome NP and Muttukrishna S (2001) Effect of cytokines and growth factors on the secretion of inhibin A, activin A and follistatin by term placental villous trophoblasts in culture European Journal of Endocrinology 145 505-511

Muttukrishna S, George L, Fowler PA, Groome NP and Knight PG (1995) Measurement of serum concentrations of inhibin-A (alpha-beta A dimer) during human pregnancy Clinical Endocrinology 42 391-397

Muttukrishna S, Fowler PA, George L, Groome NP and Knight PG (1996) Changes in peripheral serum levels of total activin a during the human menstrual cycle and pregnancy Journal of Clinical Endocrinology and Metabolism 81 3328-3334

Nakamura T, Takio K, Eto Y, Shibai H, Titani K and Sugino H (1990) Activin-binding protein from rat ovary is follistatin Science 247 836-838

Nakamura T, Sugino K, Titani K and Sugino H (1991) Follistatin, an activinbinding protein, associates with heparan sulfate chains of proteoglycans on follicular granulosa cells Journal of Biological Chemistry 266 19 432-19437

Nakatani A, Shimasaki S, Depaolo LV, Erickson GF and Ling N (1991) Cyclic changes in follistatin messenger ribonucleic acid and its protein in the rat ovary during the estrous cycle Endocrinology 129 603-611

O'Connor AE, McFarlane JR, Hayward S, Yohkaichiya T, Groome NP and de Kretser DM (1999) Serum activin A and follistatin concentrations during human pregnancy: a cross-sectional and longitudinal study Human Reproduction 14 827-832

Opsjøn SL, Wathen NC, Tingulstad S, Wiedswang G, Sundan A, Waage A and Austgulen R (1993) Tumor necrosis factor, interleukin-1, and interleukin-6 in normal human pregnancy American Journal of Obstetrics and Gynecology 169 397-404

Petraglia F, Anceschi MM, Calza L, Garuti GC, Fusaro P, Giardino L, Genazzani AR and Vale W (1993) Inhibin and activin in human fetal membranes: evidence for a local effect on prostaglandin release Journal of Clinical Endocrinology and Metabolism 77 542-548

Petraglia F, Gallinelli A, De Vita D, Lewis K, Mathews L and Vale W (1994a) Activin at parturition: changes of maternal serum levels and evidence for binding sites in placenta and fetal membranes Obstetrics and Gynecology 84 278-282

Petraglia F, Gallinelli A, Grande A, Florio P, Ferrari S, Genazzani AR, Ling $\mathbf{N}$ and Depaolo LV (1994b) Local production and action of follistatin in human placenta Journal of Clinical Endocrinology and Metabolism 78 205-210
Phillips DJ, Hedger MP, McFarlane JR, Klein R, Clarke IJ, Tilbrook AJ, Nash AD and de Kretser DM (1996) Follistatin concentrations in male sheep increase following sham castration/castration or injection of interleukin1 beta Journal of Endocrinology 151 119-124

Roberts VJ and Barth SL (1994) Expression of messenger ribonucleic acids encoding the inhibin/activin system during mid- and late-gestation rat embryogenesis Endocrinology 134 914-923

Robertson DM, Klein R, de Vos FL, McLachlan RI, Wettenhall RE, Hearn MT, Burger HG and de Kretser DM (1987) The isolation of polypeptides with FSH suppressing activity from bovine follicular fluid which are structurally different to inhibin Biochemical and Biophysical Research Communications 149 744-749

Schneider-Kolsky M, D'Antona D, Evans LW, Taylor N, O'Connor A, Groome NP, de Kretser D and Wallace EM (2000) Maternal serum total activin A and follistatin in pregnancy and parturition British Journal of Obstetrics and Gynaecology 107 995-1000

Schneyer AL, Fujiwara T, Fox J, Welt CK, Adams J, Messerlian GM and Taylor AE (2000) Dynamic changes in the intrafollicular inhibin/activin/ follistatin axis during human follicular development: relationship to circulating hormone concentrations Journal of Clinical Endocrinology and Metabolism 85 3319-3330

Singh J and Adams GP (1998) Immunohistochemical distribution of follistatin in dominant and subordinate follicles and the corpus luteum of cattle Biology of Reproduction 59 561-570

Sugino K, Kurosawa N, Nakamura T, Takio K, Shimasaki S, Ling N, Titani K and Sugino H (1993) Molecular heterogeneity of follistatin, an activinbinding protein. Higher affinity of the carboxyl-terminal truncated forms for heparan sulfate proteoglycans on the ovarian granulosa cell Journal of Biological Chemistry 26815 579-15 587

Tisdall DJ, Hudson N, Smith P and McNatty KP (1994) Localization of ovine follistatin and alpha and beta A inhibin mRNA in the sheep ovary during the oestrous cycle Journal of Molecular Endocrinology 12 181-193

Tsuchida K, Arai KY, Kuramoto Y, Yamakawa N, Hasegawa Y and Sugino H (2000) Identification and characterization of a novel follistatin-like protein as a binding protein for the TGF-beta family Journal of Biological Chemistry $27540788-40796$

Ueno N, Ling N, Ying SY, Esch F, Shimasaki S and Guillemin R (1987) Isolation and partial characterization of follistatin: a single-chain $\mathrm{Mr}$ 35,000 monomeric protein that inhibits the release of follicle-stimulating hormone Proceedings National Academy of Sciences USA 84 8282-8286

Vale W, Rivier J, Vaughan J, McClintock R, Corrigan A, Woo W, Karr D and Spiess J (1986) Purification and characterization of an FSH releasing protein from porcine ovarian follicular fluid Nature 321 776-779

Wakatsuki M, Shintani Y, Abe M, Liu ZH, Shitsukawa K and Saito S (1996) Immunoradiometric assay for follistatin - serum immunoreactive follistatin levels in normal adults and pregnant women Journal of Clinical Endocrinology and Metabolism 81 630-634

Wongprasartsuk S, Jenkin G, McFarlane JR, Goodman M and de Kretser DM (1994) Inhibin and follistatin concentrations in fetal tissues and fluids during gestation in sheep: evidence for activin in amniotic fluid Journal of Endocrinology 141 219-229

Woodruff TK, Sluss P, Wang E, Janssen I and Mersol-Barg MS (1997) Activin $\mathrm{A}$ and follistatin are dynamically regulated during human pregnancy Journal of Endocrinology 152 167-174

Yokoyama Y, Nakamura T, Nakamura R, Irahara M, Aono T and Sugino H (1995) Identification of activins and follistatin proteins in human follicular fluid and placenta Journal of Clinical Endocrinology and Metabolism 80 915-921

Zwijsen A, Blockx H, Van Arnhem W, Willems J, Fransen L, Devos K, Raymackers J, Van de Voorde A and Slegers H (1994) Characterization of a rat $\mathrm{C} 6$ glioma-secreted follistatin-related protein (FRP). Cloning and sequence of the human homologue European Journal of Biochemistry 225 937-946

Received 9 January 2002

First decision 19 February 2002

Revised manuscript received 26 April 2002.

Accepted 26 April 2002. 